\title{
Environment Flexibility Design of Information Retrieval Course Learning Oriented to Task

\author{
LIU Chun
}

Sichuan College of Architectural Technology, Network Management Center, Deyang 618000, China

a52236025@qq.com

Keywords: task oriented; information retrieval; learning environment; learning task

\begin{abstract}
The information retrieval course is the an important course of information quality education in Chinese universities and colleges, on the basis of information retrieval course reform in higher vocational colleges, a new mode of learning situation teaching is proposed oriented to task. The overall design of the learning environment is taken, the retrieve demands are taken as the form of carrier, the detailed design of the learning environment is obtained, the learning situation of teaching process is analyzed, the thinking for the reform of information retrieval course in Higher Vocational colleges is broaden.
\end{abstract}

\section{Introduction}

With the great development and leap forward growth of network information, the related research of information retrieval has become the hot subject. Information retrieval course is an important course of information quality education in the Chinese universities and colleges. It can inspire students to cultivate information consciousness of college students, cultivate the information retrieval skills, and improve the moral level of college students. It plays an important role in the information quality education of College students[1,2].

In order to meet the needs of the $21 \mathrm{C}$ society and the market occupation, the task is taken as the orientation, the advanced concepts of German higher occupation education such as learning situation type is introduced in Chinese higher education. It sets off a wave of reform of the teaching mode in Higher Vocational Colleges in our country. This new teaching mode has given new vitality to the information retrieval course, but also has some problems: the learning situation is introduced from other courses mechanically, and the imitation is high. It is not suitable for carrying out the course teaching[3]; It is hard to find the starting point of learning situation, the choice of carrier form is single, design flexibility is not strong; The learning contexts among the situations are not obvious, it does not reflect the gradual learning relationship[4]. Learning situation design is the key to success or failure of the curriculum reform of information retrieval teaching mode. Combined to the information retrieval course practice of Higher Vocational Colleges, search demand is taken as the carrier form, learning environment is designed oriented to task. The learning situation of teaching process is analyzed, the thinking for the reform of information retrieval course in Higher Vocational colleges is broaden[5,6].

\section{Research status at home and abroad}

Information quality was proposed by the chairman of Information Industry Association America Paul Zekaosi in 1974, it can be understood a "all aspects of perception, information identification, acquisition, processing, utilization, creation, management and evaluation of accomplishment and quality" [7]. It is the basic quality of contemporary college students to adapt the development of the information society. The information quality education is an important component of comprehensive quality education of college students in China[8].

In recent years, our country and western developed countries refer the information quality education as an important research field, and all the international educational organizations, governments, regional governments and educational institutions vigorously promote and implement 
information quality education and research. In developed countries, such as UK, Australia, USA, Germany and Japan, they are putting effort to improve their nationals' basic information ability in twenty-first Century, to improve the survival and development ability[9].

The United States is the first country to carry out the information literacy education, information literacy education in the United States was shown as reference searching, user training, and so on, it was evolved from traditional library literature, United States government and relevant departments had paid attention to the information retrieval education in mid twentieth Century[10]. In 1983, Horton thinks that the education department should open the information literacy curriculum, in order to improve the ability of people to use online database, communication services, electronic mail, data analysis and library network. In 1985, the government launched the "2061 plan" officially; the information technology and the discipline integration thought were proposed. In 1987, the American Library Association formed the Committee for information quality education. In 1990 the United States Commission formulated the "Outline" evaluation of information quality education results on higher education, in 1996, the framework of "the function of information literacy education in the general education program" was constructed. In 1997 the United States Florida University Library and the information science college built "information literacy tutorials online resources". In 2000, American University and the association of research libraries proposed the "information literacy competency standards for higher education". The development and utilization of overseas rather focus on the education of information quality of infrastructure construction and education information resources[11].

Information literacy education in China mainly takes the University as the core, and the process of education in information retrieval course is the core. In 1984, the Ministry of Education issued "On opening the document retrieval and utilization course " opinions" notice in higher schools", colleges and universities offered requirements gradually create conditions of information retrieval course or seminar to develop the information quality education[12]. In 1985, the State Education Commission issued "Some teaching advices on the improvement and development of document retrieval". In 1992 the State Education Commission issued "basic requirements of teaching" literature retrieval. The CPC Central Committee was developed in 1999, State Council made the" Deepening education reform, comprehensively promote quality education decision", to cultivate students' information quality is an important goal of modern higher education. . In 2002, the University Library Work Committee held a national information literacy education of university academic seminar in Harbin, and it was the first class meeting Symposium on information retrieval was renamed Symposium on information literacy education, and it illustrated the importance of carrying out the information literacy education in the information retrieval course of university[13].

\section{Learning situation teaching mode based on task orientation}

The mode of teaching learning situation based on task orientation focus on working process: "complete a job task in the enterprise and a complete working procedure to obtain the results of the work, it is a comprehensive, constantly in motion, and the system structure is relatively fixed". The six steps work flows are expressed as information retrieval, decision-making, planning, implementation, examination and evaluation[14]. In the occupation demand background, this kind of teaching mode defines the information retrieval course standard and training scheme as areas of learning, it is described by three parts such as the occupation ability of learning goal, task representations of learning content, theory practice and the learning time, its core is to break the traditional teaching mode of subject system. The existing curriculum knowledge system is deconstructed, it is integrated into the enterprise occupation, work, or virtual simulation scene atmosphere, amount of knowledge is constant, and the learning content is reconstructed. Through the design of learning context, it can reflect the specific learning tasks. 


\section{General design of learning situation based on task orientation}

Learning environment is to realize the curriculum program in the learning field occupation, the target is to improve the ability of information retrieval, the learning field of information retrieval is a process of completing the work, design a number of "small" theme units composed of learning situation, specific information retrieval of learning fields is obtained, and each learning environment is also a process of work.

\section{A Design of carrier form}

Each learning situation of information retrieval learning field has bright pertinence, it can really express the working conditions and environment of the occupation, it must have the typical working process characteristics, highlight the characteristics of different occupation which present in the work such as object, content, means, organization, products and activities of the elements[14]. The forms of the carrier should be shown in the same category of things, it can be designed as type of resource, information retrieval tools, retrieval method, retrieval technology, retrieval process, retrieval requirement etc.

\section{B Design of learning task}

Learning situation can be represented by learning tasks, and each learning situation of information retrieval study areas can be decomposed into more than one clear and definite work learning tasks. Each task of learning is a complete working process.

\section{Design of learning sequence}

The arrangement of learning sequence should follow inherent law of learning and the cultivation of students' occupation ability, the basic rules and knowledge of cognition should be followed also. Between the learning situation and learning task, it can reflect the relationship $\mathrm{f}$ parallel, progressive and tolerance, mutual connection and relationship are designed, learning environment design of information retrieval learning is generally from simple to complex, from decentralized to centralized, from the traditional to the network scheduling order.

\section{Detailed learning environment design based on task orientation}

The carrier forms of learning situation chooses retrieval demand, it is grown up from several process and link to develop the necessary search point, kind of learning situation design methods can cater to the students' taste, close to the actual retrieval environment of students, it can cause resonance from students. The construction table of learning situation is described in Table 1 .

Table 1 Construction table of learning situation according to retrieval demand

\begin{tabular}{|c|c|c|c|c|c|}
\hline $\begin{array}{l}\begin{array}{r}\text { Learning } \\
\text { situation }\end{array} \\
\text { Learning tasks }\end{array}$ & $\begin{array}{l}\text { Learning } \\
\text { situation } 1 \\
\text { Entry retrieva } \\
\text { requirement }\end{array}$ & $\begin{array}{l}\text { Learning } \\
\text { situation } 2 \\
\text { Professional } \\
\text { retrieval demand }\end{array}$ & $\begin{array}{l}\text { Learning } \\
\text { situation } 3 \\
\text { Graduation } \\
\text { retrieval } \\
\text { requirement }\end{array}$ & $\begin{array}{l}\text { Learning } \\
\text { situation } 4 \\
\text { Employment } \\
\text { retrieval } \\
\text { requirement }\end{array}$ & $\begin{array}{l}\text { Learning } \\
\text { situation } 5 \\
\text { Occupation } \\
\text { retrieval } \\
\text { requirement }\end{array}$ \\
\hline $\begin{array}{l}\text { Learning task } \\
1\end{array}$ & $\begin{array}{l}\text { Freshmen } \\
\text { entering } \\
\text { library training } \\
\text { and colleg } \\
\text { history } \\
\text { education }\end{array}$ & $\begin{array}{l}\text { Combined witl } \\
\text { "Chinese Library } \\
\text { gClassification" to } \\
\text { eunderstand th } \\
\text { professional } \\
\text { subject attribute }\end{array}$ & $\begin{array}{l}\text { Find relevant } \\
\text { professional } \\
\text { references for the } \\
\text { graduation } \\
\text { design }\end{array}$ & $\begin{array}{l}\text { Find the } \\
\text { recruitment } \\
\text { website, search } \\
\text { recruitment } \\
\text { information }\end{array}$ & $\begin{array}{l}\text { Find a business } \\
\text { owned patent } \\
\text { technology }\end{array}$ \\
\hline $\begin{array}{l}\text { Learning task } \\
2\end{array}$ & $\begin{array}{l}\text { Visit } \\
\text { library, } \\
\text { recognize } \\
\text { resources } \\
\text { types }\end{array}$ & $\begin{array}{l}\text { For difficul } \\
\text { homework, use } \\
\text { retrieval } \\
\text { technology } \\
\text { quickly } \\
\text { solutions }\end{array}$ & $\begin{array}{l}\text { Writing the } \\
\text { graduation } \\
\text { thesis, search } \\
\text { related major } \\
\text { references }\end{array}$ & $\begin{array}{lr}\text { Find network } \\
\text { information as } \\
\text { the interview } \\
\text { points r and } \\
\text { matters r and } \\
\text { attentions }\end{array}$ & $\begin{array}{l}\text { Retrieve } \\
\text { enterprise } \\
\text { competitive } \\
\text { intelligence, } \\
\text { provides } \\
\text { information } \\
\text { consultant }\end{array}$ \\
\hline
\end{tabular}




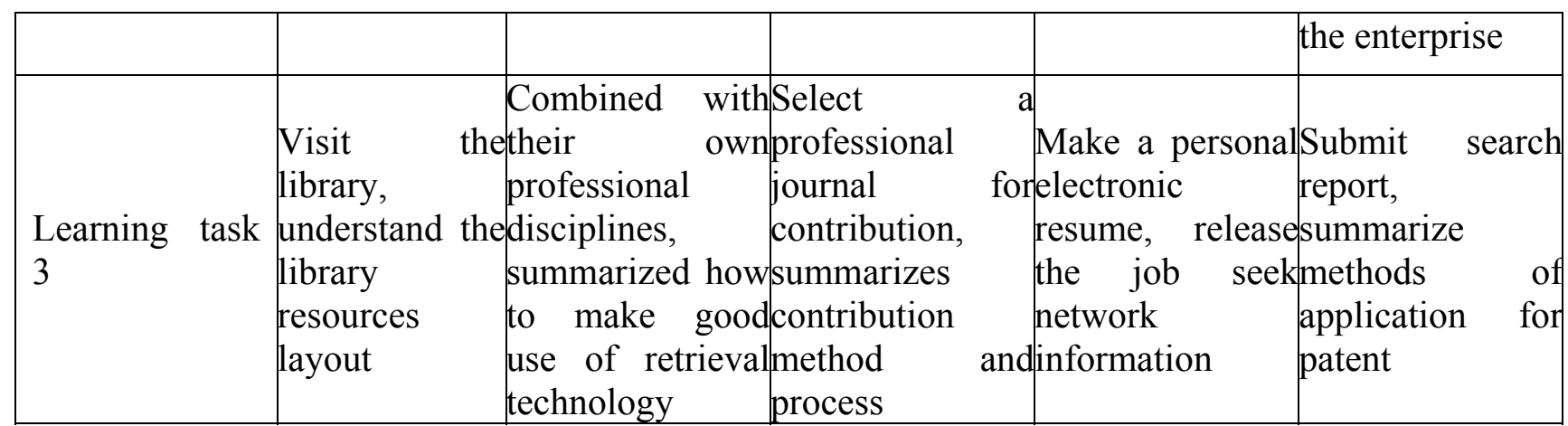

The design of transverse learning situation 1 to learning situation 5 is the process of growing from freshmen to occupation work, and it belongs to the progressive relationship. Every learning situation is completed by 3 different learning tasks to achieve, the vertical learning tasks are shown as various logical relations, learning situation 3 has 3 tasks with interlocking, it is formed the progressive relationship of retrieval difficulty coefficient gradually increases. The learning situation 2 and learning task 1 and learning tasks 2 generates parallel relationship etc..

According to the graduation destination of Vocational College Students, learning situation 4 can also be designed for different directions and employment direction upgraded retrieval demand in detail, different learning stages or occupation link need the important documents and information requirements. The progress is shown in Figure 1.

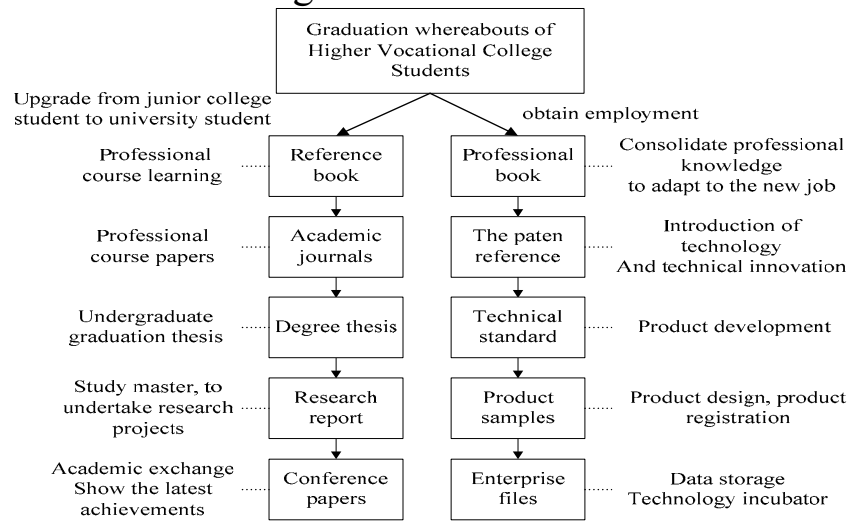

Figure 1 Retrieval demands and learning situation of higher vocational students for graduation

The design of learning carrier based on retrieval demand need to guide the students to master the methods and techniques of information retrieval system, realize the change from as "novice, proficient and expert, master". Although the search target is determined, but it does not restrict the use of what kind of retrieval tools, retrieval path selection, retrieval type structure are determined by the students themselves. The retrieval results and the ways are decided by the students themselves. It gives full play of students' creativity and autonomy. Not in order to obtain some resource types and retrieval, and nor it is learn a retrieval tools for retrieval, it has more flexibility.

\section{Teaching process of learning situation based on task orientation}

The work process is fused in the process of teaching, "six step" work flow as information retrieval, decision, planning, implementation, inspection and evaluation is transformed, it is formed new learning situation "six steps" teaching process based on task orientation. To realize the whole thinking process by learning tasks, to perform a complete search process, the work process is shown in Figure 2.
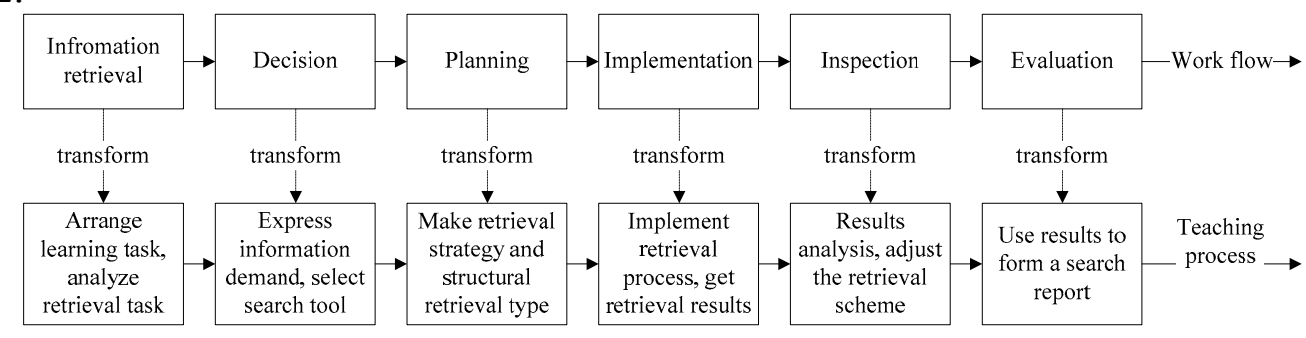
Figure 2 Transformation of work process and teaching process

\section{Conclusions}

The information retrieval course is the an important course of information quality education in Chinese universities and colleges, on the basis of information retrieval course reform in higher vocational colleges, a new mode of learning situation teaching is proposed oriented to task. Give a man a fish, as delegate to fish, students are lived in this era of information explosion, to enhance information literacy, improve information collection, we should use and update their knowledge and problem-solving overall capacity. Their experience and knowledge of information retrieval can be improved in this new mode, and the overall design of the learning environment is taken, the retrieve demands are taken as the form of carrier, the detailed design of the learning environment is obtained, the learning situation of teaching process is analyzed, the thinking for the reform of information retrieval course in Higher Vocational colleges is broaden. The knowledge of information retrieval structure is constructed, so as to improve the comprehensive ability of the students.

\section{References}

[1] Luo Liang, Wu Wen-jun, Zhang Fei. Energy Modeling Based on Cloud Data Center[J]. Journal of Software, 2014,25(7):1371-1387.

[2] Liu Chun. Network traffic prediction model based on genetic algorithm optimizing BP neural network[J]. Information Security and Technology, 2014,5(6): 82-86.

[3] Xing Ji-liang. Research on Method of Fault Information Filtering and Effective Word Frequency Estimation for Web[J]. Bulletin of Science and Technology, 2014,30(2): 59-61.

[4] Gao Zhichun, Chen Guanwei, Hu Guangbo, et al. Fault Diagnosis and Optimal Data Clustering Based on K-Means with Slope Factor[J]. Computer \& Digital Engineering, 2014, 42(1): 14-18.

[5] Liu Chun. Network Intrusion Detection Model Based on Combination Algorithm Selecting Features[J]. Computer and Modernization, 2014,(8):75-80.

[6] Cao Jian, Li Hai-sheng, Cai Qiang. Research on Feature Extraction of Image Target[J]. Computer Simulation, 2013; 30(1): 409-413.

[7] Jiang Yun, Chen Na, Mming Li-te, et al. Bagging-based probability Neural Network Ensemble Classification Algorithm[J]. Computer Science, 2013; 40(5): 242-246.

[8] Wang Ya-nan. Higher vocational learning environment of information retrieval curriculum design work process oriented[J]. Research on Library Science, 2013,(3):85-87.

[9] Liu Chun. Optimization Algorithm of Large Network Database Based on Data Files Chaos Characteristic[J]. Bulletin of Science and Technology, 2014,30(6): 82-84.

[10] Wang Ya-nan. Study on Task-Oriented Working Process Teaching Reform of Information Retrieval Course in Higher Vocational College, Library and Information Service, 2009, (23):91-94.

[11] Liu Chun. Network intrusion detection model based on artificial fish swarm algorithm optimizing neural network[J]. Network \& Computer Security, 2014,(7):2-5.

[12] Ahn J, Hong S, Heidemann J. An adaptive FEC code control algorithm for mobile wireless sensor networks [J]. Journal of Communications and Networks, 2005, 7(4): 489-499.

[13] Felemban E, Lee C U, Ekici E. MMSPEED; multi-path multi-speed protocol for QoS guarantee of reliability and timeliness in wireless sensor networks[J]. IEEE Transactions on Mobile Computing, 2008, 5(6):738-76.

[14] Chi K, Jiang X, Horiguchi S. Network coding-based reliable multicast in wireless networks[J]. Computer Networks, 2010, 11(4): 1823-1836. 